\title{
The Integration of People Convicted of a Sexual Offence Into the Community and Their (Risk) Management
}

\author{
K. F. McCartan ${ }^{1} \cdot$ K. Richards ${ }^{2}$ \\ Accepted: 27 May 2021 / Published online: 1 July 2021 \\ (C) The Author(s) 2021
}

\begin{abstract}
Purpose of Review We are reviewing recent research into the community integration of men convicted of a sexual offence and their (risk) management. This is a high-profile political issue that binds together research in psychology, criminology, politics, health, public health, and policy studies. The review will demonstrate that a multi-disciplinary, life course, EpiCrim-oriented approach is the most effective way of reducing re-offending and promoting desistance in this population.

Recent Findings Research demonstrates that life course development, especially from psychology and criminology, has an impact on whether people sexually offend or not. Therefore, to understand sexual offending behaviour, we need to look at the aetiology of said behaviour from a nature and a nurture perspective. Therefore, we need to use an Epidemiological Criminology (a marriage of Public Health and criminology) approach that works at all four stages of the Socio-Ecological Model (SEM) (individual, interrelationship, community, and societal). The research encourages a person first approach, that we look at Adverse Childhood Experiences and past trauma in the lives of men who sexually offend and use this, in conjunction with strength-based approaches, to inclusively integrate them into society.

Summary The prevention of sexual offending, both first time offending, and relapse prevention require a multi-level, multidisciplinary approach. Successful desistance from sexual offending is as much about the community and society as it is about the individual.
\end{abstract}

Keywords People who have sexually offended · Community integration · Risk management · Multi-disciplinary approaches . Multi-agency approaches $\cdot$ Epidemiological criminology

\section{Introduction}

Sexual abuse and sexual offending are high level socio-political, policy, media, and community issues [1-3] which transverse all levels of society and are present across all countries [4-9]. Since the 1970s [10, 11], arguably the major starting point for research into sexual abuse, we have seen the emergence of several narratives linked to sexual abuse and how best to respond to it $[1,12 \bullet \cdot$. In today's socio-political climate, even before the advent of the \#metoo movement [13], sexual offending was viewed as a high-profile issue that

This article is part of the Topical Collection on Sexual Disorders

K. F. McCartan

kieran.mccartan@uwe.ac.uk

1 University of the West OF England, Bristol, UK

2 Queensland University of Technology, Brisbane, Australia factored in political debates [14-16], media coverage [17-20], and public discourses [3, 18, 21-24]. Often these public debates were, and still are, punitive in nature [25-28, 29•] and viewed within a risk management framework [11, 15, 30]. In recent years, this punitive discourse around sexual offences has started to shift with the introduction of public health [21, 31-34] and life-course [35-39] perspectives that reinforce strengths-based approaches $[40,41 \bullet, 42]$ and desistance pathways $[28 \bullet \bullet, 43,44]$. This article discusses how the incorporation of public health approaches is starting to change the policy, practice, and messaging around the community integration of people who have sexually offended.

\section{Definitional Challenges and Their Impact on Sexual Abuse}

It is important to understand that defining sexual offences is complex and can vary widely within and among different 
countries as well as legal jurisdictions [3, 45-48]. This legal complexity is further compounded by the context within which the offence happens, the nature of the offence, the impact upon the victim/survivor, and the demographics of the person committing it $[1,12 \cdot \bullet]$. This means that sentencing and related outcomes [i.e. incarceration, treatment] are casedependent and varied. This is problematic as it can result in the perception that the criminal justice response to sexual offending is inconsistent and not fit for purpose [49-53]. Unfortunately, this works to erode trust in the criminal justice system by victim/survivors [49, 54-57], which has resulted in an increase in the under-reporting of sexual offences [54]. Determining the true scale of sexual offending is therefore difficult. While it is difficult to determine the actual prevalence of sexual abuse, research indicates that it is higher compared to official data. [58]. Prevalence studies indicate that, in Public Health terms, sexual abuse is an epidemic [21], and that the people who commit sexual offences are less likely to be abnormal "monsters" and more likely to be likely to be representative members of society [28••].

\section{Current Approaches to Community Risk Management}

Current responses to sexual offending are rooted in the criminal justice processes $[15,46,59]$. Traditionally, most individuals convicted of a serious sexual offence will receive a prison sentence, or a suspended prison sentence to be served in the community, in conjunction with a treatment or rehabilitation programme tied to the nature of their offence and the risk they pose $[9,60,61]$. Rehabilitation is based on the underlying principle that people can and want to change and is delivered though a Cognitive-Behavioural framework that uses strength-based models and pro-social behaviour modelling $[1,12 \bullet, 62,63 \bullet \bullet, 64-68]$. In recent years, we have seen a de-pathologising of people who commit sexual offences as it is no longer accepted that all people who commit sexual offences have a severe mental illness [69-71]. Instead, we are seeing that inclusion IN treatment programmes is being determined not by their offence but instead by level of anti-sociality, any co-morbidities and risk of re-offending [69-71]. This emphasises that rehabilitation needs to be bespoke to the individual [72-76]. However, paradoxically, we see punitive criminal justice policies, often replicated internationally [3, $15,46,77]$, that run contrary to the desistance and harm reduction messages of rehabilitation [28••]. These harmful and problematic policies include the use of polygraph testing [78, 79], registration and/or community notification policies [80-82], housing restrictions [83, 84], and limitations on employment $[85,86]$. The reason why these policies can reduce the successful community integration of people convicted of a sexual offence is that they identify them as an "other", limit integration, and reduce said individuals' opportunity to change. The reality is that in attempting to protect the community and safeguard citizens, these policies often increase risk rather than reduce it $[28 \bullet \bullet, 44,68,87]$. This is clearly evidenced by the fact that prolonged community inclusion reduces risk longitudinally [1]. We are starting to see a growth in community-based and community-driven interventions for people convicted of sexual offences that are rooted in the desistance framework, including the increased use of restorative justice [88, 89], and Circles of Support and Accountability [90,91]. Although, a lot of new community interventions are developed and implemented based on professional knowledge and expertise, they need more research and evaluation before they can be determined to be effective in supporting community integration. In addition to helping with the rehabilitation and management of people convicted of a sexual offence, these innovations in community integration interventions help improve the public's knowledge on sexual abuse and therefore improve public attitudes to and openness for community integration [92].

\section{Understanding the Role and Function of Strengths-Based Approaches in Integrating People Convicted of a Sexual Offence}

In recent years, we have seen continued growth in strengthsbased approach to the treatment and rehabilitation of people convicted of a sexual offence, with increased focus on the Good Lives Model and pro-social inclusion [1, 12••, 63••, $64,65,72-74]$. The strengths-based approach to rehabilitation reinforces that rehabilitation is a process rather than an outcome [28••]. This reinforces that behaviour change is learnt and that Cognitive-Behavioural approaches, in which most programmes/interventions for individuals convicted of a sexual offence are rooted, are a logical way forward [93, 94]. A strengths-based approach is important in rehabilitation because it emphasises that a person is more than their offence, that they have strengths as well as deficits, and that by building upon these strengths they can change their problematic behaviour; therefore, increasing their ability to successfully integrate into the community.

\section{Using a Multi-disciplinary Approach to Understand Sexual Offending}

In responding to sexual abuse, we need to examine the behaviour of the person who committed it from several perspectives [95], which means considering their psychology, wellbeing, mental health, family and peer relationships, employment, education, lifestyle, and socio-demographic factors $[1,46,96$, 97]. Evidence indicates that of people who commit sexual 
offences are not radically different from individuals who commit other offences [98], and that we need better understand the impact of developmental and social factors, important factors that highlight the impact of nature and nurture, on the lives people who commit sexual offences $[3,15]$. Therefore, we need to better unify psychological, social, health, and wellbeing research in this arena [99]. One method for doing this is by using an Epidemiological Criminology (EpiCrim) approach $[100,101]$. EpiCrim understands and responds to crime at a population level by using public health approaches that work at an individual, interpersonal, community, and societal level across all four stages of prevention (primary, secondary, tertiary, and quaternary) $[10,98,102]$. An EpiCrim approach emphasises the importance of individual, their relationships, and wider social context so that we can better understand their pathways into offending as well as develop fit for purpose rehabilitation programmes. The EpiCrim approach is starting to be used in the field of sexual offender risk management and community integration, $[10,42,98$, 102-104]]. Additionally, taking an EpiCrim approach has moved the narrative around community integration and risk management away from a purely professional one to a more community based one with increased education [10, 102], bystander intervention training [105-107], and community integration programmes/interventions [108-110]. An EpiCrim approach reinforces that sexual abuse is a community as well as an in individual issue, and therefore needs an integrated, multi-faceted community response.

\section{From Multi-Disciplinary to Multi-Agency Approaches: Theory to Practice}

One cannot take a siloed approach to understanding the aetiology, process, treatment, and/or management of people convicted of a sexual offence. Instead, we need a multi-disciplinary approach that emphasises that sexual offending, like all offending, is created from a series of different "events" or "processes" in a person's life (i.e. what works approach-111). Effective community integration and risk management needs an individualised approach that includes all the relevant agencies and organisations who work with the service user $[41 \bullet, 45$, 112-115]. Hence, we need to put the person who committed the sexual offence at the heart of the rehabilitation and community integration process [68, 116-118]. Not only does a bespoke EpiCrim approach to community integration help in the prevention of reoffending, but it can also help in the prevention of first time offending by giving us insight into the way that individuals think about their offending, their pathways into it, and it allows us to hear from the service user-potentially the most effective means of intervening.

\section{What "Successful" Community Integration Looks Like}

One of the main challenges in the community integration of people convicted of a sexual offence is articulating what success looks like. Community management policies are impacted by Key Performance Indicators (KPIs) related to the criminal justice organisations, charities, and non-government organizations that must execute them. Generally, success is measured in terms of "re-conviction" rather than "reoffending" $[119,120]$ or "harm reduction" $[74,102,121]$. This is problematic because someone can re-offend and not get caught. Further, individuals may re-offend at a lower rate, or in a different way, from their original offending behaviour $[62,63 \cdot \bullet]$. Therefore, the question must be asked: is there a better way of identifying risk, managing risk, and measuring success? Should we be looking at harm reduction and desistance $[28 \bullet \bullet, 43,44,87]$ as a means of identifying continued, or changing, risk $[30,119,122,123]$ ?

If we are serious about sexual offending being a multidisciplinary and multi-agency issue, we need to better understand how other organisations, and fields, develop and evidence their KPI's so that we can make ours fit for purpose. This means that we should look at success criteria in violence prevention [124], addiction studies [125], and health [126], among other fields, and build a new, more tailored approach to measuring success. People who commit sexual offences generally have low re-conviction rates $[62,63 \bullet \bullet, 127]$, are compliant with community management strategies [28••, $128,129]$, and those who do re-offend commonly do so at a lower level than their original offences $[62,63 \bullet \bullet]$. Hence, we are starting from a low base rate and trying to understand why a smaller population goes on to reoffend while the larger group does not. Therefore, methodologically, qualitative research and case studies work better in desistance focused research projects as we want to better understand individual behaviours to build more effective interventions. However, these approaches offer methodological challenges in many innovative interventions and community integration projects globally, where sample sizes are small and impact limited $[109,130]$, as opposed to the larger treatment and risk assessment studies where the programmes and bodies of work are based on similar theoretical constructs [131]. This means, methodologically speaking, that large scale randomised controlled trials may not be the most effective method for understanding individual change and effective risk management [132], with the best projects potentially being a combination of quantitative and qualitative research to give a rounded view.

A final issue with the "success" criterion in integration is that it is not based on success, but on failure. We currently measure an individual's success by whether they re-offend, not by how they have changed their lives or progressed along 
a desistance pathway [68]. In redeveloping KPIs we need to make sure that pro-social, progressive ones are included [36, 109], and understand the difference between a lack of reoffending and the development of a genuine commitment to desistance [133].

\section{Developing Fit for Purpose Policies and Practices}

Criminal justice policies are usually reactionary in nature [46, 59] and can be poorly thought out in respect to cost or the challenges of implementation [3]. This is particularly true of sexual offense policies. In taking an EpiCrim approach, we need to reconsider the policy development and implementation on the community integration of people convicted of a sexual offence. All too often, policy development in this area is based on the impact of highprofile cases [for instance, Adam Walsh and Jacob Wetterling in the USA, Sarah Payne in the UK], public opinion, and media perspectives, with little consideration of the evidence base [134•, 135]. It would be safer to say that sexual offence policy tends to be evidence informed or ideologically driven rather than evidence based $[15,46,136]$; therefore, we need to take a more nuanced approach. In doing this, we need to be more client centred. In our field, when we are talking about patient or client involvement, we are discussing people who have either been a victim of or perpetrated sexual abuse [137••]; although, neither are central to the policy making process. Although the views of victim/survivors shape the development of sexual offense policy and practice [138], these tend to be those perspectives that fit with the pre-existing policy and practice positions. Alternative victim/survivor views - such as support for progressive measures including restorative measures [139, 140] or Circles of Support and Accountability [109] — are often marginalised. The development of informed, evidence-based, and nuanced community integration practice must come with an upskilling and education of the public in general, and policy makers specifically, about the complexity of sexual abuse. It is important to develop policy that enables desistance, rather than results in the individual failing, breaching, relapsing, and ultimately re-offending. Sexual abuse policy must enable good practice in rehabilitation and integration to occur, not stifle it. Therefore, we need a dual track policy and practice process that can be reactive and thoughtful. This means an ongoing process of research, development, and review. Community integration policy and practice needs to be constant and evolving, and not, as it is currently, sporadic and reactionary.

\section{Conclusion}

The integration of people who have committed sexual offences back into the community is a difficult balancing act between risk management, public protection, and community relations. What we have seen in recent years, in line with the evolution of our understanding of general offending behaviour, is an emphasis on sexual offending as a health, life course, and well-being issue. This emphasises the importance of focusing on the person rather than the offence and, therefore, of partnership in the way that we collectively integrate people who have committed a sexual offence back into the community. The changing landscape in the community integration of people convicted of a sexual offence opens opportunities for new partnerships, improved funding streams, and a concrete, coherent multi-disciplinary approach. The reality of this new landscape of community integration is that people who commit sexual offences come from communities; therefore, communities have a role to play in their ongoing risk management and desistance.

Open Access This article is licensed under a Creative Commons Attribution 4.0 International License, which permits use, sharing, adaptation, distribution and reproduction in any medium or format, as long as you give appropriate credit to the original author(s) and the source, provide a link to the Creative Commons licence, and indicate if changes were made. The images or other third party material in this article are included in the article's Creative Commons licence, unless indicated otherwise in a credit line to the material. If material is not included in the article's Creative Commons licence and your intended use is not permitted by statutory regulation or exceeds the permitted use, you will need to obtain permission directly from the copyright holder. To view a copy of this licence, visit http://creativecommons.org/licenses/by/4.0/.

\section{References}

Papers of particular interest, published recently, have been highlighted as:

- Of importance

- Of major importance

1. Lussier P, Beauregard E. Sexual offending: a criminological perspective. 1st ed. Routledge: New York; 2018.

2. Nair, P. (2019). Child sexual abuse and media: coverage, representation, and advocacy. Institutionalised Children Explorations and Beyond, 6, 1, pp. 38-45 https://doi.org/10.5958/2349-3011. 2019.00005.7.

3. McCartan KF, Gotch K. International approaches to the Management of Perpetrators of sexual harm policy: preventative, practical, or political? In: Proulx J, Cortoni F, Craig LA, Latourneau E, editors. The Wiley handbook of what works with sexual offenders: contemporary perspectives in theory, assessment, treatment, and prevention. London: Wiley; 2020. Chapter 25.

4. Seigfried-Spellar, K. C., \& Soldino, V. (2020). Child sexual exploitation: introduction to a global problem. In T. J. Holt, A. M. Bossler (eds.), The Palgrave Handbook of International Cybercrime and Cyberdeviance. Chapter 56. https://doi.org/10. 1007/978-3-319-78440-3 53

5. National Sexual Harm Resource Center (2015). Media packet: Campus sexual assault. Harrisburg, PA: National Sexual Harm Resource Centre. Accessed on 28-08-20202 from http://www. 
nsvrc.org/publications/nsvrc-publications-fact-sheets/mediapacket-campus-sexual-assault

6. UNICEF (2014). Hidden in plain sight. New York, NY: author. Retrieved from http://files.unicef.Org/publications/files/Hidden in plain_sight_statistical_analysis_EN_3_Sept_2014.Pdf

7. World Health Organization (2014). Global status report on violence prevention 2014. Geneva, Switzerland: Author. Retrieved from $\mathrm{http} / / \mathrm{www}$.who.int/violence injury prevention/violence/ status_report/2014/report/report/en

8. McCartan, K., Uzieblo, K., \& Smid, W. J. (2020). Professionals' understandings of and attitudes to the prevention of sexual Abuse: an international exploratory study. International Journal of Offender Therapy and Comparative Criminology. 0.1177/ $0306624 X 20919706$

9. McCartan KF (Ed.) (2018). Special issue: international approaches to the assessment and management of people who have committed sexual abuse. Sexual Offender Treatment, 13(1/2).

10. Brown J. Public health, prevention, and risk management. In: McCartan K, Kemshall H, editors. Perceptions of sex offender risk management. London, England: Palgrave; 2017. p. 35-60.

11. Kemshall $\mathrm{H}$. The historical evolution of sex offender risk management. In: McCartan K, Kemshall H, editors. Contemporary sex offender management, vol. 1. London, England: Palgrave; 2017. p. 1-34.

12.• Proulx, J., Cortoni, F., Craig, L. A., \& Latourneau, E. (2020). The Wiley handbook of what works with sexual offenders: contemporary perspectives in theory, assessment, treatment, and prevention. Wiley: London. The most up to date, comprehensive overview of the field of sexual offending.

13. Kaufman MR, Dey D, Crainiceanu C, Dredze M. \#MeToo and Google inquiries into sexual violence: a hashtag campaign can sustain information seeking. Journal of Interpersonal Violence. 2019. https://doi.org/10.1177/0886260519868197.

14. Beauregard E, Lieb R. Sex offenders and sex offender policy. In: Wilson JQ, Petersilia J, editors. Crime \& Public Policy. Oxford: Oxford University Press; 2011. Chapter12.

15. McCartan KF. Moving forward from the crossroads: the importance of translating the sexual offence evidence into effective policy and practice. In: Uzieblo K, Smid W, McCartan K, editors. At the Crossroads. London: Palgrave Macmillian; 2021. Chapter 18.

16. Munro VE. Shifting sands? Consent, context and vulnerability in contemporary sexual offences policy in England and Wales. Soc Leg Stud. 2017;26(4):417-40. https://doi.org/10.1177/ 0964663916682584

17. Weathered JL. Framing child sexual abuse: A longitudinal content analysis of newspaper and television coverage, 2002-2012. Journal of Child Sexual Abuse. 2017;26(1):3-22. https://doi.org/ 10.1080/10538712.2016.1257528.

18. Harper CA, Hogue TE. Press coverage as a heuristic guide for social decision-making about sexual offenders. Psychol Crime Law. 2017;23(2):118-34.

19. Popović S. Child sexual abuse news: a systematic review of content analysis studies. Journal of Child Sexual Abuse. 2018;27(7): 752-77. https://doi.org/10.1080/10538712.2018.1486935.

20. Waller L, Dreher T, Hess K, McCallum K, Skogerbø E. Media hierarchies of attention: news values and Australia's Royal Commission into institutional responses to child sexual abuse. Journal Stud. 2020;21(2):180-96. https://doi.org/10.1080/ 1461670X.2019.1633244.

21. Tabachnick J, McCartan K, Panaro R. Changing course: from a victim/offender duality to a public health perspective. In: Laws R, O'Donoghue W, editors. Treatment of sex offenders: strengths and weaknesses in assessment and intervention. Cham, Switzerland: Springer; 2016. p. 323-42.

22. Vertommen T, Kampen J, Schipper-van Veldhoven N, Uzieblo K, Van Den Eede F. Severe interpersonal violence against children in sport: associated mental health problems and quality of life in adulthood. Child Abuse Negl. 2018;76:459-68.

23. Wright K, Swain S, McPhillips K. The Australian Royal Commission into institutional responses to child sexual abuse. Child Abuse Negl. 2017;74:1-9. https://doi.org/10.1016/j. chiabu.2017.09.031

24. Richards K. Born this way? A qualitative examination of public perceptions of the causes of pedophilia and sexual offending against children. Deviant Behav. 2018;39(7):835-51. https://doi. org/10.1080/01639625.2017.1335526.

25. Kras KR, Morgan M, Pleggenkuhle B, Huebner BM. Compounded stigmatization: collateral consequences of a sex offence conviction. In: Huebner BM, Frost NA, editors. Handbook on the consequences of sentencing and punishment decisions. New York: Routledge; 2019. Chapter 11.

26. Harper CA, Hogue TE, Bartels RM. Attitudes towards sexual offenders: what do we know, and why are they important? Aggress Violent Behav. 2017;34:201-13.

27. Socia KM, Rydberg J, Dum CP. Punitive attitudes toward individuals convicted of sex offenses: a vignette study. Justice Q. 2019:1-28. https://doi.org/10.1080/07418825.2019.1683218.

28.• Harris, D. (2017). Desistance from sexual offending: Narratives of retirement, regulation, and recovery. Palgrave Macmillan. A well rounded, critical examination of desistence in practice with men convicted of a sexual offence.

29. Harper CA, Harris AJ. Applying moral foundations theory to understanding public views of sexual offending. J Sex Aggress. 2017;23(2):111-23. https://doi.org/10.1080/13552600.2016. 1217086 An interesting multi-disciplinary piece on the links between public opinion and morality.

30. Wilson RJ, Sandler JC, McCartan KF. Community dynamic risk management of persons who have sexually offended. In: Proulx J, Cortoni F, Craig LA, Latourneau E, editors. The Wiley handbook of what works with sexual offenders: contemporary perspectives in theory, assessment, treatment, and prevention. London: Wiley; 2020. Chapter 14.

31. Singh MM, Parsekar SS, Nair SN. An epidemiological overview of child sexual abuse. Journal of family medicine and primary care. 2014;3(4):430-5. https://doi.org/10.4103/2249-4863.148139.

32. Letourneau EJ, Schaeffer CM, Bradshaw CP, Feder KA. Preventing the onset of child sexual abuse by targeting young adolescents with universal prevention programming. Child Maltreatment. 2017;22(2):100-11. https://doi.org/10.1177/ 1077559517692439.

33. Mathews B, Collin-Vézina D. Child sexual abuse: raising awareness and empathy is essential to promote new public health responses. J Public Health Policy. 2016;37:304-14. https://doi.org/ 10.1057/jphp.2016.21.

34. Mathews B. Optimising implementation of reforms to better prevent and respond to child sexual abuse in institutions: insights from public health, regulatory theory, and Australia's royal commission. Child Abuse Negl. 2017;74:86-98. ISSN 0145-2134. https://doi.org/10.1016/j.chiabu.2017.07.007.

35. Lussier P, McCuish E. A developmental life-course view of sexual offending: taking stock of research on the life-course development of antisocial and criminal behavior. In: Proulx J, Cortoni F, Craig LA, Latourneau E, editors. The Wiley handbook of what works with sexual offenders: contemporary perspectives in theory, assessment, treatment, and prevention. London: Wiley; 2020. Chapter 3.

36. McCartan KF (2020). Trauma-informed practice HM Inspectorate of Probation Academic Insights 2020/05.

37. Simi P, Sporer K, Bubolz BF. Narratives of childhood adversity and adolescent misconduct as precursors to violent extremism: A life-course criminological approach. J Res Crime Delinq. 2016;53(4):536-63. https://doi.org/10.1177/0022427815627312. 
38. Lussier P, Blokland AAJ. A developmental life-course perspective of juvenile and adult sexual offending. In: Sanders T, editor. The Oxford handbook of sex offences and sex offenders. Oxford: Oxford University Press; 2017. Chapter 14.

39. McGee TR, Whitten T, Williams C, Jolliffe D, Farrington DP. Classification of patterns of offending in developmental and lifecourse criminology, with special reference to persistence. Aggress Violent Behav. 2020:101460. https://doi.org/10.1016/j.avb.2020. 101460.

40. Kewley, s. Strength based approaches and protective factors from a criminological perspective. Aggress Violent Behav. 2017;32: 11-8. https://doi.org/10.1016/j.avb.2016.11.010.

41. Kewley S. Policing people with sexual convictions using strengths-based approaches. Journal of Criminal Psychology. 2017;7(3):168-82. https://doi.org/10.1108/JCP-09-2016-0026 An interesting article on how to police using a strengths based, not deficit based, approach.

42. Merdian H, Kettleborough D, McCartan K, Perkins DE. Strengthbased approaches to online child sexual abuse: using selfmanagement strategies to enhance desistance behaviour in users of child sexual exploitation material. Journal of Criminal Psychology. 2017;7(3):182-91. https://doi.org/10.1108/JCP-102016-0035.

43. McAlinden A-M, Farmer M, Maruna S. Desistance from sexual offending: do the mainstream theories apply? Criminol Crim Just. 2017;17(3):266-83. https://doi.org/10.1177/1748895816670201.

44. Harris DA, Laws R. Desistance and the rise of rehabilitation. In: Lussier P, Beauregard E, editors. Sexual offending: a criminological perspective. 1st ed. Routledge: New Yotrk; 2018. Chapter 5.

45. Thomas T. Policing sexual offences and sex offenders. London: Palgrave Macmillan; 2016.

46. Rolfe SM, Tewsbury R. Criminal justice policies: the intended and unintended consequences of monitoring individuals convicted of sex crimes. In: Lussier P, Beauregard E, editors. Sexual offending: A criminological perspective. 1st ed. Routledge: New York; 2018. Chapter 4.

47. Council for Penological Co-operation (2020). Terms of reference valid from: 1 January 2020 until 31 December 2021. Official memo, Accessed on 28-08-2020 via https://rm.coe.int/adoptedtor-pc-cp-2020-2021-eng/168098e921

48. World Health Organization (2012). Understanding and addressing violence against women: Sexual violence. Accessed 28-08-2020 via https://apps.who.int/iris/bitstream/handle/10665/77434/ W H O R H R 12.37 eng.pdf; j s s s i on id= AC516F4635B1309752C930E31A8EB8E0?sequence=1

49. Thompson L, Rydberg J, Cassidy M, Socia KM. Contextual influences on the sentencing of individuals convicted of sexual crimes. Sex Abus. 2020;32(7):778-805. https://doi.org/10.1177/ 1079063219852936.

50. Freiberg A. Institutional responses to the sentencing recommendations of the Royal Commission into institutional responses to child sexual abuse. Criminal Law Journal. 2020;44(2):127-43.

51. Benedet J. Sentencing for sexual offences against children and youth: mandatory minimums, proportionality and unintended consequences. Queens Law J. 2018;44:284-315.

52. Coburn PI, Chong K, Connolly DA. The effect of case severity on sentence length in cases of child sexual assault in Canada. Journal of Child Sexual Abuse. 2017;26(3):319-33. https://doi.org/10. 1080/10538712.2017.1283651.

53. Sentencing council (2013). Sexual Offences: Response to Consultation. Sentencing Council. Accessed on 28-08-2020 via https://www.sentencingcouncil.org.uk/wp-content/uploads/ Final_Sexual_Offences_Response_to_Consultation_web1.pdf

54. Independent Inquiry into Child Sexual Abuse (2018). Interim Report of the Independent Inquiry into Child Sexual Abuse.
Accessed on 28-08-2020 via https://www.iicsa.org.uk/ publications/inquiry/interim

55. Rydberg J, Cassidy M, Socia KM. Punishing the wicked: examining the correlates of sentence severity for convicted sex offenders. J Quant Criminol. 2018;34:943-70. https://doi.org/10. 1007/s10940-017-9360-y.

56. Duron JF. Legal decision-making in child sexual abuse investigations: a mixed-methods study of factors that influence prosecution. Child Abuse Negl. 2018;79:302-14. https://doi.org/10.1016/ j.chiabu.2018.02.022.

57. Walker S-JL, Hester M, McPhee D, Patsios D, Williams A, Bates $\mathrm{L}$, et al. Rape, inequality, and the criminal justice response in England: the importance of age and gender. Criminol Crim Just. 2019. https://doi.org/10.1177/1748895819863095.

58. Office for National Statistics (2018). Sexual offending: victimisation and the path through the criminal justice system. Office for National Statistics. Accessed on 28-08-2020 via https://www.ons.gov.uk/ peoplepopulationandcommunity/crimeandjustice/articles/ sexualoffendingvictimisationandthepaththroughthecriminaljusticesystem/2018-12-13

59. Kang HW (2017). The punitive effect of victim-focused discourse on legislative responses to child sexual abuse: examining the influence of the USA on England and Wales and South Korea. PhD Thesis. Queens University of Belfast. Accessed on 28-08-2020 via https://ethos.bl.uk/OrderDetails.do?uin=uk.bl.ethos.727409

60. Crown Prosecution service (2020). Sentencing. Rape and Sexual Offences. Chapter 19. Accessed on the 28-08-2020 via https:// www.cps.gov.uk/legal-guidance/rape-and-sexual-offenceschapter-19-sentencing

61. Rotenberg, C. (2017). From arrest to conviction: court outcomes of police-reported sexual assaults in Canada, 2009 to 2014. Statistics Canada. Accessed on 28-08-2020 via https://www150. statcan.gc.ca/n1/pub/85-002-x/2017001/article/54870-eng.htm

62. Mews A, Di Bella L, Purver M (2017). Impact evaluation of the prison-based Core Sex Offender Treatment Programme. Ministry of Justice analytical series. Ministry of Justice: London.

63.• Gannon TA, Olver ME, Mallion JS, James M (2019). Does specialized psychological treatment for offending reduce recidivism? A meta-analysis examining staff and program variables as predictors of treatment effectiveness, Clinical Psychology Review, 73. https://doi.org/10.1016/j.cpr.2019.101752. The most up to date meta-analysis of the treatment of people convicted of a sexual offence.

64. Jones ACT, Neal TMS. A call for research on sex offender treatment programs. International Journal of Offender Therapy and Comparative Criminology. 2019;63(1):77-85. https://doi.org/10. 1177/0306624X18786608.

65. Kim B, Benekos PJ, Merlo AV. Sex offender recidivism revisited: review of recent meta-analyses on the effects of sex offender treatment. Trauma Violence Abuse. 2016;17(1):105-17. https://doi. org/10.1177/1524838014566719.

66. Blagden, N., \& Winder, B. (2019). Helping to rehabilitate sex offenders is controversial - but it can prevent more abuse. The Conversation. Accessed on 28-08-2020 via https:// theconversation.com/helping-to-rehabilitate-sex-offenders-iscontroversial-but-it-can-prevent-more-abuse-111861

67. Fedoroff JP. Can people with Paedophilia change? Yes they can! Curr Sex Health Rep. 2018;10:207-12. https://doi.org/10.1007/ s11930-018-0166-1.

68. McCartan, K. F., Harris, D. A., \& Prescott, D. S. (2019). Seen and not Heard: The Service User's Experience Through the Justice System of Individuals Convicted of Sexual Offenses. International Journal of Offender Therapy and Comparative Criminology. https://doi.org/10.1177/0306624X19851671 
69. Moulden H, Marshall L. Major mental illness in those who sexually abuse. Curr Psychiatry Rep. 2017;19:105. https://doi.org/10. 1007/s11920-017-0863-x.

70. Lewis ET, Dwyer RG. Psychosis and sexual offending: A review of current literature. International Journal of Offender Therapy and Comparative Criminology. 2018;62(11):3372-84. https://doi.org/ 10.1177/0306624X17740016.

71. Moulden HM, Abracen J, Looman J, Kingston DA. The role of major mental illness in problematic sexual behavior: current perspectives and controversies. In: Proulx J, Cortoni F, Craig LA, Latourneau E, editors. The Wiley handbook of what works with sexual offenders: contemporary perspectives in theory, assessment, treatment, and prevention. London: Wiley; 2020. Chapter 20

72. Thornton D, Kelley SM, Nelligan KE. Protective factors and mental illness in men with a history of sexual offending. Aggress Violent Behav. 2017;32:29-36. https://doi.org/10.1016/j.avb. 2016.12.003.

73. Willis GM, Prescott DS, Yates P. Application of an integrated good lives approach to sexual offending treatment. In: Beech A, Ward T, Craing L, Rettenberger M, Marshall L, Marshall W, editors. The Wiley-Blackwell handbook on the assessment, treatment and theories of sexual offending. Singapore: John Wiley \& Sons; 2016. Chapter 64.

74. Haffernan R, Ward T. The good lives model and the rehabilitation of individuals convicted of sexual offending. In: O'Donohue WT, Schewe PA, editors. Handbook of sexual assault and sexual assault prevention. Switzerland: Springer; 2019. p. 515-34.

75. Schmucker M, Lösel F. Sexual offender treatment for reducing recidivism among convicted sex offenders: a systematic review and meta-analysis. Campbell Syst Rev. 2017;13(1):1-75. https:// doi.org/10.4073/csr.2017.8.

76. Lösel F, Schmucker M. Treatment of sex offenders: concepts and empirical evaluations. In: Sanders T, editor. The Oxford handbook of sex offences and sex offenders. Oxford: Oxford University Press; 2017. Chapter 21.

77. Cochran JC, Toman EL, Shields RT, Mears DP. A uniquely punitive turn? Sex Offenders and the Persistence of Punitive Sanctioning. J Res Crime Delinq. 2020;58:74-118. https://doi. org/10.1177/0022427820941172.

78. Wood JL, Alleyne E, O' Ciardha C, Gannon TA (2020). An evaluation of polygraph testing by police to manage individuals convicted or suspected of sexual offending. University of Kent

79. Elliott E, Vollm B. The utility of post-conviction polygraph testing among sexual offenders. Sex Abus. 2018;30(4):367-92. https:// doi.org/10.1177/1079063216667922.

80. Cubellis MA, Walfield SM, Harris AJ. Collateral consequences and effectiveness of sex offender registration and notification: law enforcement perspectives. International Journal of Offender Therapy and Comparative Criminology. 2018;62(4):1080-106. https://doi.org/10.1177/0306624X16667574.

81. Connor DP, Tewsbury R. Public and professional views of sex offender registration and notification. Criminology, Criminal Justice, Law \& Society. 2017;18:1-27.

82. Bouffard JA, Askew LN. Time-series analyses of the impact of sex offender registration and notification law implementation and subsequent modifications on rates of sexual offenses. Crime Delinq. 2019;65(11):1483-512. https://doi.org/10.1177/ 0011128717722010 .

83. Mogavero MC, Kennedy LW. The social and geographic patterns of sexual offending: is sex offender residence restriction legislation practical? Vict Offenders. 2017;12(3):401-33. https://doi.org/ 10.1080/15564886.2015.1084962.

84. Savage J, Windsor C. Sex offender residence restrictions and sex crimes against children: A comprehensive review. Aggress
Violent Behav. 2018;43:13-25. https://doi.org/10.1016/j.avb. 2018.08.002.

85. Levenson J, Cotter L. The impact of sex offender residence restrictions: 1,000 feet from danger or one step from absurd? International Journal of Offender Therapy and Comparative Criminology. 2005;49(2):168-78.

86. Wacquant, L. (2009). Punishing the poor: the neoliberal government of social inseurity Durham: Duke University press.

87. Farmer M, McAlinden A-M, Maruna S. Understanding desistance from sexual offending: A thematic review of research findings. Probat J. 2015;62(4):320-35. https://doi.org/10.1177/ 0264550515600545 .

88. Koss M. The RESTORE program of restorative justice for sex crimes: vision, process, and outcomes. Journal of Interpersonal Violence. 2014;29(9):1623-60.

89. McGlynn C, Westmarland N, Godden N. 'I just wanted him to hear me': sexual violence and the possibilities of restorative justice. J Law Soc. 2012;39(213-240):213-40.

90. Fox K. Theorizing community integration as desistance-promotion. Crim Justice Behav. 2015;42(1):82-94.

91. Fox K. Civic commitment: promoting desistance through community integration. Punishment Soc. 2016;18(1):68-94.

92. Bartels L, Walvisch J, Richards K (2019) More, longer, tougher... or is it finally time for a different approach to the post-sentence management of sex offenders in Australia? Criminal Law Journal

93. Mpofu E, Athanasou JA, Rafe C, Belshaw SH. Cognitivebehavioral therapy efficacy for reducing recidivism rates of moderate- and high-risk sexual offenders: A scoping systematic literature review. International Journal of Offender Therapy and Comparative Criminology. 2018;62(1):170-86. https://doi.org/ 10.1177/0306624X16644501.

94. Harrison JL, O’Toole SK, Ammen S, Ahlmeyer S, Harrell SN, Hernandez JL. Sexual offender treatment effectiveness within cognitive-behavioral programs: a meta-analytic investigation of general, sexual, and violent recidivism. Psychiatry Psychol Law. 2020;27(1):1-25. https://doi.org/10.1080/13218719.2018. 1485526.

95. Nunes KL, Pedneault CI, Filleter WE, Maimone S, Blank C, Atlas M. "I Know Correlation Doesn't Prove Causation, but ...": Are We Jumping to Unfounded Conclusions About the Causes of Sexual Offending? Sex Abus. 2019;31(2):220-36. https://doi. org $/ 10.1177 / 1079063217729156$.

96. Sanders T. The Oxford handbook of sex offences and sex offenders. Oxford: Oxford University Press; 2017.

97. Farrington DP. The development of violence from age 8 to 61 . Aggress Behav. 2019;45(4):365-76.

98. Wortley R, Smallbone S. A criminal careers typology of child sexual abusers. Sexual Abuse: A Journal of Research and Treatment. 2014;26(6):569-85.

99. Herbert JL, Bromfield L. Better together? A review of evidence for multi-disciplinary teams responding to physical and sexual child abuse. Trauma Violence Abuse. 2019;20(2):214-28. https://doi.org/10.1177/1524838017697268.

100. Waltermaurer E, Akers TA. Epidemiological criminology: theory to practice. London: Routledge; 2013.

101. Lainer MM. Epidemiological criminology (EpiCrim): definition and application. Journal of Theoretical and Philosophical Criminology. 2014;2(1):63-103.

102. McCartan K, Kemshall $\mathrm{H}$. The potential role of recovery capital in stopping sexual offending: lessons from circles of support and accountability to enrich practice. Irish Probation Journal. 2020;20.

103. Knack N, Winder BM, Murphy L, Fedoroff JP. Primary and secondary prevention of child sexual abuse. International Review of Psychiatry. 2019;31(2):181-94. https://doi.org/10.1080/ 09540261.2018 .1541872 . 
104. Risser HJ, Svevo-Cianci K, Karim EJ, Morford AE. Achieving comprehensive prevention of child abuse and neglect. Int Journal on Child Malt. 2020;3:63-79. https://doi.org/10.1007/s42448019-00024-7.

105. Levine M, Philpot R, Kovalenko AG. Rethinking the bystander effect in violence reduction training programs. Soc Issues Policy Rev. 2019;14(1):273-96. https://doi.org/10.1111/sipr.12063.

106. Davidov D, Bush HM, Clear ER, Coker AL. Using a multiphase mixed methods triangulation design to measure bystander intervention components and dose of violence prevention programs on college campuses. J Fam Violence. 2020;35:551-62. https://doi. org/10.1007/s10896-019-00108-5.

107. Butler LC, Fisher BS (2020). Who are the mavens of bystander intervention? Implications for the Social Diffusion of Intervention Norms Journal of Interpersonal Violence https://doi.org/10.1177/ 0886260520934431

108. Rye BJ, Hovey A, Waye L. Evaluation of a restorative justice-based, community-based program for people who have offended sexually: participant impact. Contemporary Justice Review. 2018;21(3):27698. https://doi.org/10.1080/10282580.2018.1494373.

109. Richards K, Death J, McCartan K (2020). Community-based approaches to sexual offender reintegration. NSW, Australia: Australia's National Research Organisation for Women's safety (ANROWS)

110. Logan WA. Community-based approaches to sex offender management. In: Proulx J, Cortoni F, Craig LA, Latourneau E, editors. The Wiley handbook of what works with sexual offenders: contemporary perspectives in theory, assessment, treatment, and prevention. London: Wiley; 2020. Chapter 23.

111. Crassati J. The rehabilitation of sexual offenders: complexity, risk and desistance. London: Routledge; 2018.

112. Nash M, Williams A. Handbook of public protection. London: Willian; 2010.

113. Cowburn M, Duggan M, Pollock E. Working with different values: extremism, hate and sex crimes. In: Cowburn $\mathrm{M}$, Duggan M, Robinson A, Senior P, editors. Values in criminology and community justice. Bristol: Polity Press; 2015. Chapter 20.

114. Rauth J, Bromberg DS. Supervision of sex offenders and sexually violent predators in community settings. In: O'Donohue WT, Bromberg DS, editors. Sexually violent predators: a clinical science handbook. Switzerland: Springer; 2019. p. 379-401.

115. Pycroft A, Gough D. Multi-agency working in criminal justice: theory, policy and practice. 2ND ed. Polity Press: Bristol; 2019.

116. Birgden A, Ward T. Ethical sex offender treatment. In: Beech A, Ward T, Craing L, Rettenberger M, Marshall L, Marshall W, editors. The Wiley-Blackwell handbook on the assessment, treatment and theories of sexual offending. Singapore: John Wiley \& Sons; 2016. Chapter 74.

117. Carter AJ, Mann R. The strengths of treatment for sexual offending. In: Laws DR, O'Donohue WT, editors. Treatment of sex offenders: strengths and weaknesses in assessment and intervention. Switzerland: Springer; 2016. Chapter 7.

118. Howard MVA, de Almeida Neto AC, Galouzis JJ. Relationships between treatment delivery, program attrition, and reoffending outcomes in an intensive custodial sex offender program. Sex Abus. 2019;31(4):477-99. https://doi.org/10.1177/1079063218764886.

119. Wijetunga C, Picard E, Rosenfeld B. Management of sex offenders in community settings. In: O'Donohue WT, Bromberg DS, editors. Sexually violent predators: a clinical science handbook. Switzerland: Springer; 2019. p. 379-92.

120. Bartels L, Weatherburn D. Building community confidence in community corrections. Curr Issues Crim Just. 2020;32:292 308. https://doi.org/10.1080/10345329.2020.1801150.

121. McAlinden AM. Risk, regulation, and the reintegration of sexual offenders. In: Trotter C, Mclvor G, McNeill F, editors. Beyond the risk paradigm in criminal justice: Red Globe Press; 2016. Chapter 8.
122. Laws DR. Social control of sex offenders: a cultural history. London: Palgrave Macmillan; 2016.

123. Nash M. MAPPA: sex offenders and managing 'the other' in the community. In: Pycroft A, Gough D, editors. Multi-agency working in criminal justice: theory, policy and practice. 2ND ed. Polity Press: Bristol; 2019. Chapter 5.

124. Wormith SJ, Craig LA, Hogue TE. The Wiley handbook of what works in violence risk management theory, research, and practice. London: Wiley Blackwell; 2020.

125. Kolind T, Thom B, Hunt G. The SAGE handbook of Drug \& Alcohol Studies: social science approaches. London: Sage; 2016.

126. Hilliard ME, Riekert KA, Ockene JK, Pbet L. The handbook of health behavior change. 5th ed. Springer: Switzerland; 2018.

127. Hanson RK, Harris AJR, Letourneau E, Helmus LM, Thornton D. Reductions in risk based on time offense-free in the community: once a sexual offender, not always a sexual offender. Psychol Public Policy Law. 2018;24(1):48-63. https://doi.org/10.1037/ law0000135.

128. Levenson J. Community control of sex offenders. In: Laws DR, O'Donohue WT, editors. Treatment of sex offenders: strengths and weaknesses in assessment and intervention. Switzerland: Springer; 2016. Chapter 10.

129. Levenson JS. Sex offender management policies and evidencebased recommendations for registry reform. Curr Psychiatry Rep. 2018;20:21. https://doi.org/10.1007/s11920-018-0884-0.

130. Wakeling H, Saloo F. An exploratory study of the experiences of a small sample of men convicted of sexual offences who have reoffended after participating in prison-based treatment. HM Prison \& Probation: Analytical Summary; 2018.

131. Lösel F, Link E, Schmucker M, Bender D, Breuer M, Carl L, et al. On the effectiveness of sexual offender treatment in prisons: A comparison of two different evaluation designs in routine practice. Sex Abus. 2020;32(4):452-75. https://doi.org/10.1177/ 1079063219871576 .

132. Deaton A, Cartwright N. Understanding and misunderstanding randomized controlled trials. Soc Sci Med (1982). 2018;210:221. https://doi.org/10.1016/j.socscimed.2017.12.005.

133. Cooley B, Sample L. The difference between desistance from sexual offending and not reoffending. J Crime Justice. 2018;41(5):483-503.

134. Tabachnick, J., \& Klein, A. (2011). A reasoned approach: reshaping sex offender policy to prevent child sexual abuse. Association for the Treatment of Sexual Abusers.

135. Human Rights Watch (2013). Raised on the registry: the irreparable harm of placing children on sex offender registries in the US. Human Rights Watch.

136. Parkhurst J. The politics of evidence: from evidence-based policy to the good governance of evidence. Abingdon, Oxon, UK: Routledge; 2017.

137.• Willis, G. M., \& Letourneau, E. (2018). Promoting Accurate and Respectful Language to Describe Individuals and Groups. Sex Abus, 30(5) 480-483 A seminal piece on the importance of using first person language.

138. Levenson J, Brannon Y, Fortney T, Baker J. Public perceptions about sex offenders and community protection policies. Anal Soc Issues Public Policy. 2007;7(1):137-61.

139. Jülich S. Views of justice among survivors of historical child sexual abuse: implications for restorative justice in New Zealand. Theor Criminol. 2006;10(1):125-38.

140. Marsh F, Wager N. Restorative justice in cases of sexual violence: exploring the views of the public and survivors. Probat J. 2012;62(4):336-56

Publisher's Note Springer Nature remains neutral with regard to jurisdictional claims in published maps and institutional affiliations. 